\title{
Offshore renewable energy: ecological implications of generating electricity in the coastal zone
}

\author{
ANDREW B. GILL \\ Institute of Water and Environment, Cranfield University, Silsoe, Bedfordshire MK45 4DT, UK
}

\begin{abstract}
Summary
1. Global-scale environmental degradation and its links with non-renewable fossil fuels have led to an increasing interest in generating electricity from renewable energy resources. Much of this interest centres on offshore renewable energy developments (ORED). The large scale of proposed ORED will add to the existing human pressures on coastal ecosystems, therefore any ecological costs and benefits must be determined. 2. The current pressures on coastal ecology set the context within which the potential impacts (both positive and negative) of offshore renewable energy generation are discussed. 3. The number of published peer-review articles relating to renewable energy has increased dramatically since 1991. Significantly, only a small proportion of these articles relate to environmental impacts and none considers coastal ecology.

4. Actual or potential environmental impact can occur during construction, operation and/or decommissioning of ORED.

5. Construction and decommissioning are likely to cause significant physical disturbance to the local environment. There are both short- and long-term implications for the local biological communities. The significance of any effects is likely to depend on the natural disturbance regime and the stability and resilience of the communities.

6. During day-to-day operation, underwater noise, emission of electromagnetic fields and collision or avoidance with the energy structures represent further potential impacts on coastal species, particularly large predators. The wider ecological implications of any direct and indirect effects are discussed.

7. Synthesis and applications. This review demonstrates that ORED will have direct and, potentially, indirect consequences for coastal ecology, with these effects occurring at different scales. Ecologists should be involved throughout all the phases of an ORED to ensure that appropriate assessments of the interaction of single and multiple developments with the coastal environment are undertaken.
\end{abstract}

Key-words: coastal ecology, coastal environmental impact, enhancement, habitat disturbance, resilience, stability

Journal of Applied Ecology (2005) 42, 605-615

doi: $10.1111 /$ j.1365-2664.2005.01060.x

\section{Introduction}

The generation of electricity from renewable energy resources is fast becoming a key objective of many countries. The driving force behind this is the link between non-renewable fossil fuels and environmental

Correspondence: Andrew B. Gill, Institute of Water and Environment, Cranfield University, Silsoe, Bedfordshire MK45 4DT, UK (fax +44 1525 863334;

e-mail a.b.gill@cranfield.ac.uk). degradation (Dincer 1999; Chow, Kopp \& Portney 2003). Climate change is a major concern, leading to predictions of a global temperature rise of $3-5^{\circ} \mathrm{C}$ within 50 years and an increase in climatic variability (Houghton et al. 2001). Although the consequences of climate change are currently the subject of much debate, from an ecological standpoint the concern arises from evidence of geographical shifts in the distribution of species (Pounds \& Puschendorf 2004), predictions of a sharp increase in extinction probability for many plant and animal species (Thomas et al. 2004) 
and wider impacts on ecosystems (Leemans \& Eickhout 2004). Add to this the predicted decline in the amounts of non-renewable resources over the next few decades (Pimentel et al. 2002) and it is clear that alternatives to fossil fuels are needed.

Countries with coastlines have particularly valuable renewable energy resources, in the form of tides, currents, waves and offshore wind. Coastal waters are extensive and the associated renewable energy resources are plentiful and predictable (Pelc \& Fujita 2002). In addition, the perceived aesthetic problem of siting large numbers of energy-generating devices (e.g. wind turbines) in terrestrial landscapes is reduced by locating them offshore. Not surprisingly, therefore, considerable attention is now being directed towards coastal waters in an effort to harness offshore renewable energy sources.

Coastal zones, however, are already under significant pressure from human activity as a result of their high biological productivity and accessibility (Blaber et al. 2000) and their provision of valuable ecosystem services and functions (Costanza et al. 1997). It is imperative, therefore, that the implications of generating electricity from offshore renewable sources are appropriately assessed with regard to the current ecological status of the coastal zone and the potential consequences.

\section{EXISTING COASTAL ECOLOGICAL STATUS}

Major changes to coastal ecosystems are attributable to human activities. Pressure from fisheries has dramatically reduced biomass, changed diversity, altered local trophic and community structure, and degraded habitat (Blaber et al. 2000; Pauly et al. 2002). Largescale oil and gas operations have been implicated in the perturbation of the coastal environment (Holdway 2002), and other industrial processes have led to bioaccumulation of contaminants(Matthiessen \& Law 2002), abnormal development of invertebrates (Fichet, Radenac \& Miramand 1998), endocrine disruption (Tyler, Jobling \& Sumpter 1998), nutrient enrichment, toxic algal blooms and deoxygenation (Carpenter et al. 1998).

A variety of terrestrial land uses and near-shore activities (Mason 2002; Matthiessen \& Law 2002) have led to local habitat loss and disturbance, changes to nutrient status and cycling, loss of food supplies, erosion, reduced sediment supply, changes in the level of sea inundation and increased exposure to natural disturbances (McLusky, Bryant \& Elliott 1992; Schekkerman, Meininger \& Meire 1994; Rogers \& McCarty 2000).

Offshore renewable energy developments (ORED) will also impact on coastal ecosystems because single developments have ecological footprints extending over several square kilometres of near-shore waters. Larger ORED (with individual footprints approximately $20-50 \mathrm{~km}^{2}$ or greater), located adjacent to each other, are planned for the future. Such developments will require proper consideration of any potential impact on the ecosystem at appropriate spatial and temporal scales. However, our current understanding

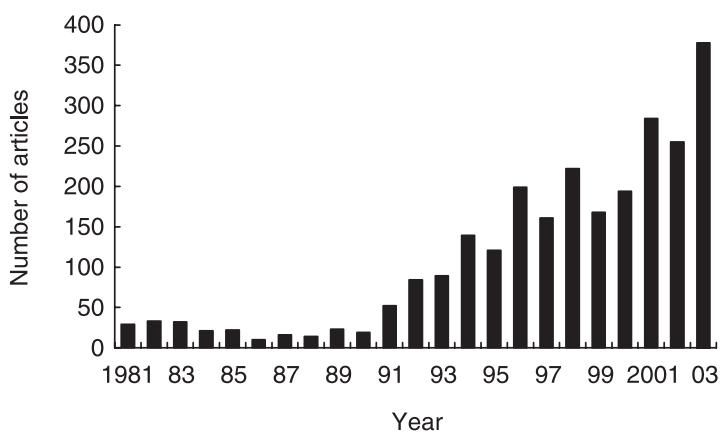

Fig. 1. The number of peer-reviewed articles with the term renewable energy (or derivative terms) published between 1981 and 2003. Web of Science data from the expanded Science Citation Index, Social Science Citation Index and the Arts and Humanities Citation Index.

of the effects of human activity on the coastal environment is limited and piecemeal (Mann 2000).

It was the aim of this study to provide an integrated review of the potential ecological implications of offshore renewable energy generation in the coastal environment at different scales.

\section{CURRENT SCIENTIFIC KNOWLEDGE RELATING TO RENEWABLE ENERGY}

The general growth of interest in renewable energy is well illustrated by the significant increase in the number of published scientific articles over the last 10 years (Fig. 1). However, only $7 \cdot 6 \%$ of these articles related to environmental impacts, whether positive or negative, and just $4 \cdot 0 \%$ have specifically considered the ecological implications of harnessing any renewable energy source. More importantly, less than $1 \%$ of the articles considered the potential environmental risks of renewable energy exploitation and none was specifically related to coastal ecology. Ecological factors are not being considered properly and are underrepresented in any discussion of the costs and benefits of adopting offshore renewable energy sources.

\section{Offshore renewable energy developments}

\section{DIRECT EFFECTS ON COASTAL ENVIRONMENT}

ORED currently encompass wind, wave, tidal and current power, with offshore wind power being the most actively pursued (Byrne \& Houlsby 2003). All ORED convert a renewable energy source into electricity via energy-generation devices (e.g. turbines and hydrofoils). To convert sufficient energy to be economically viable requires a large expanse of seabed for the device foundations and related structures to fix the devices in place.

Different degrees of physical disturbance will occur during the three phases of the life of an ORED: 1, construction; 2 , routine operation; 3 , decommissioning. It is generally assumed that the direct effects of decommissioning a site will be similar to those associated with 

offshore renewable energy

(C) 2005 British

Ecological Society, Journal of Applied Ecology, 42, 605-615 construction. Two further specific considerations are the type and extent of seabed covered by the development, and the extent of cabling. These aspects are summarized in Fig. 2.

During construction and decommissioning the seabed will be disturbed by work on the foundations for the energy conversion devices and any associated substations and the underwater power cables between devices and the main connection to shore. Removal of sediments will lead to direct loss of habitats and there will be an increase in local water turbidity arising from suspended solids. Resuspended sediments will be transported by prevailing water movement during construction, which may also mobilize any contaminants within the sediments.

Mobilized sediments may smother the neighbouring habitats of sedentary species. For ORED using current or tidal energy, the effects of suspended sediment may extend downstream. Resuspension of sediments high in organic matter, such as in estuaries and tidal reaches of rivers, will probably temporarily reduce available oxygen because of an increased biochemical oxygen demand. No published studies have assessed the ecological implications of ORED construction, so evidence from benthic habitats that have been fished or subjected to marine dredging is used to discuss possible consequences (Fig. 2).

Species assemblages within sediments exhibit natural variation spatially and through time as a result of biotic interactions and environmental disturbance. Nevertheless, fishing- and dredging-related disturbance have been shown to alter local species diversity and population density (Blyth et al. 2004). The magnitude of the effects on the benthic community and the length of time that they are apparent depend on the duration and intensity of the disturbance (Van Dalfsen et al. 2000) and the resilience of the local infauna (Drabsch, Tanner \& Connell 2001). Areas that suffer least from natural disturbance are affected by fishing activity to a greater extent (Kaiser \& Spencer 1996).

After fishing or dredging has ceased, recolonization takes from months to years (Harvey, Gauthier \& Munro 1998; Bradshaw et al. 2000). Small opportunistic species, such as polychaetes and amphipods, are the quickest to colonize after physical disturbance, while epifaunal species assemblages are likely to take longer (Harvey, Gauthier \& Munro 1998; Newell et al. 2004). Change may be rapid with soft substrata, and new habitat can be created if the conditions are suitable. On coarse and more stable substrata, change is likely to be slower (Kaiser \& Spencer 1996).

A conceptual model proposed by Jennings, Kaiser \& Reynolds (2001) suggests that as sedimentary habitats become more stable, so the effects of fishing disturbance are more extreme and longer lasting. This applies both to the structure and composition of the benthic assemblage and the topography and physical structure of the sediment. Evidence from fishing shows that the level of disturbance can also affect composition of the community at local and regional scales (Hall 1994), and removal of ecological engineering species can have devastating consequences for local biodiversity and ecosystem processes (Coleman \& Williams 2002).

Assuming fishing- and dredging-related disturbance to be analogous to construction and decommissioning of an ORED, a local loss of sedentary infauna and reef builders would be expected, while non-sedentary marine benthos would be displaced. Ecologically it is important to understand the susceptibility of species and their resilience to the effects of ORED construction/decommissioning and the processes determining community recovery after the disturbance. Implicit in this understanding is knowledge of the stability of the substrata on which the ORED is constructed.

A major difference between ORED and other human impacts in near-shore waters is the extensive subsurface structures present following construction. These structures may affect local water movements, which are fundamental to some aquatic species (Montgomery et al. 2000) and also determine the transportation and deposition of sediments.

Although the effects of decommissioning an ORED are assumed to be the same as those associated with its construction, the one obvious difference is the removal of the existing undersea structures. Removal of longestablished ORED will immediately reduce habitat heterogeneity and take out a large component of the benthic community. Indirect effects, such as changes to local food web interactions and habitat availability, may also occur, similar to those associated with fishing (Kaiser \& Jennings 2002). This will depend on species and community susceptibility and resilience to the changes.

\section{OTHER DIRECT EFFECTS}

Significant marine noise and vibration will occur during construction piling and drilling, and noise will also be emitted during the operational phase, together with electromagnetic (EM) fields associated with electricity production. The significance of these two disturbances will strongly depend on their frequency, intensity and duration in relation to the sensitivity of the organisms and their ability to habituate to the noise or EM field. A further disturbance relates to organisms colliding with or avoiding the energy-generation devices.

\section{Noise}

Foundation construction and cable laying have been shown to produce noise up to $260 \mathrm{~dB}$ re: $1 \mu \mathrm{Pa}$ and $178 \mathrm{~dB}$ re: $1 \mu \mathrm{Pa}$, respectively (Nedwell, Langworthy \& Howell 2004). These significant sources of noise could cause damage to the acoustic systems of species within $100 \mathrm{~m}$ of the source, and are expected to cause mobile organisms to avoid the area (Nedwell, Langworthy \& Howell 2004). Any effects of the noise will depend on the sensitivity of the species present and their ability to habituate to the noise, and will reduce when the level of 


\begin{tabular}{|c|c|c|c|}
\hline ORED activity & Effectors & Effects on coastal environment & Potential ecological response \\
\hline $\begin{aligned} \text { Construction } \\
-\quad \text { energy conversion device } \\
-\quad \text { substation } \\
-\quad \text { cables }\end{aligned}$ & 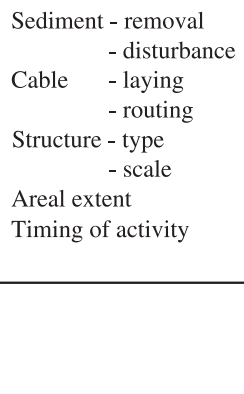 & $\begin{array}{l}\text { Habitat removal } \\
\text { Smothering - species } \\
\quad \text { - habitat } \\
\text { Increased turbidity } \\
\text { Contaminant remobilization } \\
\text { Increased BOD } \\
\text { Increased noise and vibration }\end{array}$ & $\begin{array}{l}\text { Sedentary species } \\
\text { Reduced diversity } \\
\text { Increase in opportunist abundance } \\
\text { Mobile species } \\
\text { Temporary displacement } \\
\text { Long-term displacement } \\
\text { Short-term changes to: } \\
\text { - nutrient availability } \\
\text { - diversity and abundance } \\
\text { - production and biomass } \\
\text { - community and size structure } \\
\text { - connectivity } \\
\text { Indirect effects }\end{array}$ \\
\hline
\end{tabular}

\begin{tabular}{|c|c|c|c|}
\hline Operation & $\begin{array}{ll}\text { Cable } & \text { - rating } \\
& \text { - array configuration } \\
\text { Electricity } & \text { - amount } \\
& \text { - frequency } \\
& \text { - variability } \\
\text { Moving parts } \\
\text { Structure } & \text { - type } \\
& \text { - scale }\end{array}$ & 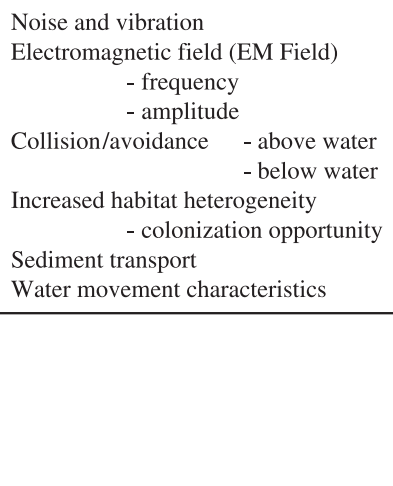 & \begin{tabular}{l} 
Acoustic species \\
Individual disturbance \\
Population disturbance \\
EM Field sensitive species \\
Individual attraction/avoidance \\
Population attraction/avoidance \\
Altered migration - temporary \\
\multicolumn{1}{c}{ - long term } \\
Injury/fatality of individuals \\
Long-term changes to: \\
- nutrient availability \\
- diversity and abundance \\
- production and biomass \\
- community and size structure \\
- connectivity \\
Indirect effects
\end{tabular} \\
\hline
\end{tabular}

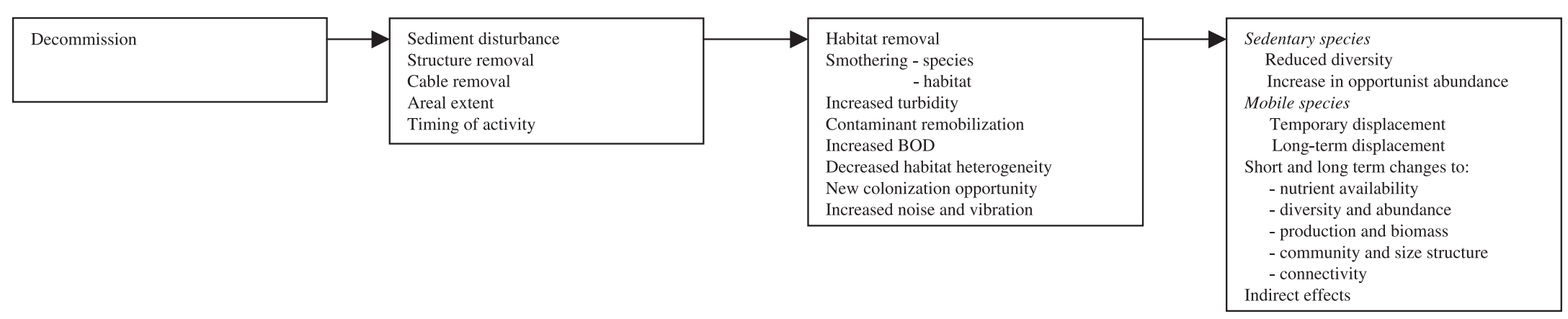

Fig. 2. Renewable energy developments and ecologically relevant interactions (refer to text for details). 

offshore renewable energy

(C) 2005 British

Ecological Society, Journal of Applied Ecology, 42, 605-615 noise has decreased following completion of the construction (or decommissioning) phase.

The potential disturbances to birds and people from noise and vibrations generated by the operation of the wind turbines are also considered important in ORED environmental impact assessments. Current opinion is that by being located offshore the noise will be less detectable by humans. However, any effects of ORED operational noise on birds have not yet been investigated, although noise from human activity on land has been shown to reduce the local abundance of birds (Forman \& Deblinger 2000; Fernandez-Juricic 2001). Breeding seabirds are known to be disturbed by human recreational activity (Dunnet et al. 1990; Beale \& Monaghan 2004) and underwater noise has been used to reduce predation pressure on molluscs by waterfowl (Ross, Lien \& Furness 2001).

Underwater, where a large number of species from very different taxa interact acoustically (e.g. cetaceans, pinnipeds, teleosts and crustaceans; Bradbury \& Veherencamp 1998), the potential for disturbance from long-term ORED operation is high. Sound is used for communication (Lugli, Yan \& Fine 2003), finding prey, echolocation (particularly by marine mammals; Tyack \& Clark 2000), locating recruitment sites in fish (Simpson et al. 2004), finding potential mates and avoiding predators (Popper \& Fay 1993). Fish have shown startle and alarm responses when encountering a loud noise (e.g. $>150 \mathrm{~dB}$ re: $1 \mu \mathrm{Pa}$; Blaxter, Gray \& Denton 1981; Pearson, Skalski \& Malme 1992). More recent studies have demonstrated a link between underwater noise and changes to the auditory threshold of some species of freshwater fish $(0 \cdot 3-2 \cdot 0 \mathrm{kHz}, 142 \mathrm{~dB}$ re: $1 \mu \mathrm{Pa}$; Scholik \& Yan 2002). However, this is not the case for all species, as some freshwater fish have evolved a strategy using different parts of the sound spectrum for communication (around $0 \cdot 1 \mathrm{kHz}, 85-110 \mathrm{~dB}$ re: $1 \mu \mathrm{Pa}$ ), effectively adapting to local ambient noise (Lugli, Yan \& Fine 2003).

Research on the effects of anthropogenic noise in the coastal environment is limited (Popper et al. 2003) but studies suggest that marine species are exposed to noises from a variety of sources (Harwood \& Wilson 2001). Research on existing offshore wind farms along Baltic Sea coasts (Hoffman et al. 2000; Fristedt, Moren \& Soderberg 2001) has shown that the acoustic environment is added to by the operation of the wind turbines $(0 \cdot 001-0 \cdot 4 \mathrm{kHz}, 80-110 \mathrm{~dB}$ re: $1 \mu \mathrm{Pa})$, and the level of acoustic disturbance is likely to be a function of the number of turbines and their operating procedure and timing at lower frequencies.

Clearly it is important to establish whether the type, frequency and intensity of sounds associated with ORED will have any implications (such as reaction or habituation) for the species that inhabit or migrate through the coastal environment. Analysis of the spatial and temporal behavioural of sensitive species in concert with measurements of the acoustic environment is required.

\section{Electromagnetic fields}

The high voltage alternating current (AC) and direct current (DC) cables that transmit power between devices and the mainland have the potential to interact with aquatic animals that are sensitive to electric (E) and magnetic (B) fields. This affects mainly fish, particularly the elasmobranchs, and marine mammals that use the Earth's magnetic field to navigate. In addition, some species utilize E fields behaviourally.

Industry standard AC cables effectively shield against direct $\mathrm{E}$ field emissions but cannot completely shield the magnetic component. The configuration of the cables and the leakage of B fields results in induced E fields adjacent to the cable independent of burial, as a result of magnetic properties (CMACS 2003). The EM field emissions are tiny from a human perspective (Fristedt, Moren \& Soderberg 2001) but they come within the range of bioelectrical emissions utilized by electrosensitive species. EM fields relating to ORED with DC cables have yet to be determined, but the focus is likely to be on the current transmitted between sea electrodes (Walker 2001).

If the induced $\mathrm{E}$ fields emanating from submarine cables can be detected by electrosensitive species, then at levels that approximate the bioelectric fields of natural prey there is potential for these species to be attracted to them. Whether such species will be attracted or repelled by stronger fields is unknown at present, but will be dependent on them passing close to the E fields (Kalmijn 1982). Elasmobranchs are attracted to DC fields in the range $0 \cdot 005-1 \mu \mathrm{V} \mathrm{cm}-1$ and avoid DC fields of approximately $10 \mu \mathrm{V} \mathrm{cm}-1$ or greater (Kalmijn 1982). There is little research to date on the effects of AC E fields (Kalmijn 1988) and only physiological studies of the frequency of emission detectable by electrosensitive fish (Bodznick \& Boord 1986; Tricas \& New 1998). Such studies suggest that lowfrequency AC emissions in the environment are more likely to be detected (Kalmijn 1988). Electrosensitive species may be attracted or repelled by the E fields, potentially resulting in congregation or dispersal depending on the extent of the electrical environment where multiple cable arrays exist. Therefore, research into the effects of ORED-related E fields on sensitive species, particularly benthic ones, is required, especially when assessing the ORED environmental impact at important local feeding or breeding grounds or nursery areas.

Magnetosensitive species occur in coastal waters world-wide (e.g. migratory fish, elasmobranchs, mammals, chelonians and crustaceans) and these species are thought to be sensitive to the Earth's magnetic fields (Wiltschko \& Wiltschko 1995). Whether there is any link between these organisms and the magnetic fields associated with an ORED is again unknown.

A B field equal to that of the Earth's magnetic field (approximately $50 \mu \mathrm{T}$ ) can be detected from DC electricity cables in the Baltic Sea at a distance of $6 \mathrm{~m}$ (Walker 2001). Such a field can affect a ship's compass 
and has the potential to interact with the navigation and orientation of any animal relying on the Earth's magnetic field. Any effect may be transient as the organism moves through the area (possibly a confusion effect). Alternatively, magnetosensitive species may be attracted to or may actively avoid the area. The only published study to date on this subject suggested that the eel Anguilla anguilla could detect B fields emitted by DC cables but only a small proportion of these fish actively responded to them (Westerberg 1999).

\section{Collision and avoidance}

Organisms might collide with or actively avoid the energy-generating devices both above and below water, depending on the number, size and spacing of the devices and their moving parts, and whether the whole ORED is located along an organism's transit route. Coastal and migratory bird species are thought to be most at threat (Garthe \& Huppop 2004), particularly species that undertake frequent, short low-level flights between feeding and roosting sites (Dirksen, Spaans \& van der Winden 1996). Where large-scale migration routes coincide with ORED sites, the potential impact will only occur at certain times of the year. Increases in seasonal and local species mortality have been recorded at onshore wind turbine sites (Barrios \& Rodriguez 2004).

At present little information exists concerning aquatic fauna colliding with or avoiding offshore energy-generation devices. The greatest impact is likely to be upon migrating species where underwater turbines are located in enclosed waters such as estuaries (Dadswell \& Rulifson 1994) or where devices form an extensive barrier to movement. Any associated effects need to be considered in the context of the potential sensitivity of species, and behavioural time and energy costs in relation to the location and scale of the development (Garthe \& Huppop 2004).

\section{INDIRECT ECOLOGICAL EFFECTS}

The extensive scale of ORED is expected to result in significant displacement of the most mobile fauna (fish, marine mammals, marine reptiles, coastal birds and possibly large crustaceans and molluscs) during construction and decommissioning. During operation, shifts in the temporal or spatial distribution of the mobile fauna or changes in their numbers may also occur as a consequence of changes in the local food web dynamics, species competition, predator-prey relationships and reproduction, which operate at different spatial and temporal ecological scales (May 1994).

(C) 2005 British

Ecological Society, Journal of Applied Ecology, 42, 605-615

\section{Food availability}

Bottom-up trophic effects are likely to occur following ORED construction and decommission as a result of significant changes in the type and abundance of ben- thic species; this in turn will change food availability for higher trophic levels. The evidence from fishing and dredging, which operate at similar scales to ORED, suggests that opportunistic fauna will increase to take advantage of species that are displaced and vulnerable during physical disturbance. The large-scale removal of habitat and species following decommissioning is also likely to alter significantly local food web dynamics.

Coastal food resources have a patchy distribution (Hall, Raffaelli \& Thrush 1994). The changes to the benthos associated with an ORED will probably increase local food availability and thereby add to the network of food patches. The importance of adding to food patches will depend on the extent and distribution of other patches and their connectivity.

The energetic requirements of the foraging fauna also need to be taken into account, particularly when considering the scale of the relationship between individual foragers and food availability (Mann \& Lazier 1996). For example, larval fish are poor swimmers and have low energy reserves so will have a high dependency on locations with abundant resources at the right time or on short distances between food patches. A cetacean is less ecologically constrained, however, as it is able to move large distances between feeding areas and can eat a wide range of prey types and sizes. Hence changes to food availability associated with ORED may affect many species but the effect will be greater for the small, more geographically restricted organisms.

\section{Competition}

The number and extent of ORED will significantly change the local habitats and present new resource opportunities that may increase the use of the area by immigrant fauna. The relative density of competitors, their competitiveness and availability of alternative opportunities, will determine the ecological consequences, but the more adaptable species will be expected to dominate (Milinski \& Parker 1991). Alternatively, if habitat degradation occurs over a wider area causing species aggregation around ORED sites, then density-dependent processes resulting from increased competition will be likely to have direct and cascading effects on the local faunal composition (Pimm 1991; Daskalov 2002).

\section{Predation}

The significant changes in prey type, size and abundance arising as a result of ORED are expected to affect the predator community. Density-dependent and top-down predatory effects may result in prey depletion (Pimm 1991) and trophic cascade effects (Pauly et al. 1998; Daskalov 2002). Additionally, if predators are perturbed by ORED and their mechanisms of recovery are slow, predator- or competitive-release may occur (Pauly et al. 1998; Dulvy, Sadovy \& Reynolds 2003). Any changes that affect the dynamic link between 
611

Ecology and offshore renewable energy

(C) 2005 British

Ecological Society, Journal of Applied Ecology, 42, 605-615 a predator and its prey may result in reduced allocation of energy to other activities (e.g. reproduction and refuge) and thereby strongly influence the behaviour of the predator (Gill 2003). With large-scale ORED we may therefore see responses in the local predator community that are additional to direct effects linked with noise and/or EM fields.

The ecological effects of competition and predation in coastal waters have been shown to be considerably altered by existing human activity (Jennings, Kaiser \& Reynolds 2001; Ormerod 2003). For example, human impacts on coastal food webs have in some cases directly reduced food for seabirds, whereas in other cases, where fishing has removed larger predatory fish, seabirds have gained more food resources as a result of less competition for the smaller fish that they feed on (Tasker et al. 2000; Atkinson et al. 2003).

Hence, dynamic processes such as trophic linkage, competition and predation may be altered if the ecological changes associated with large-scale deployment of ORED are equivalent to those resulting from other industrial-scale human activities. Understanding how and when any change will manifest itself is crucial; a useful analytical approach could incorporate the effect of human activity into a trophic linkage model of coastal predators and their prey, as suggested by Stillman et al. (2001).

\section{Reproduction and recruitment}

The significant fluctuations in food and habitat availability arising through ORED could affect species reproduction, particularly species already under human pressure. There are examples of parental care species (e.g. seabirds and marine mammals) with reduced breeding success resulting from significant drops in prey abundance as a consequence of fishing (Barrett \& Krasnov 1996).

Species with little post-reproduction parental investment could also be affected by local environmental changes linked to ORED. Many species of fish, for example, use specific spawning and nursery sites. During ORED construction and decommission early life stages may be vulnerable to burial and removal. Water movements could change as a result of the presence of a large number of ORED structures. This may redistribute new recruits locally or downstream and have wider implications for communities that are driven by species that disperse over regional scales (Kinlan \& Gaines 2003).

Habitat degradation and loss is perhaps the single most effective way of slowing or preventing fish population recoveries (Dulvy, Sadovy \& Reynolds 2003). It is a particular concern when spawning grounds or nursery areas are limited in their availability or extent and the species that rely on them have small numbers of recruits, long maturation periods (e.g. elasmobranchs) and are already being impacted by other human activities (Myers \& Worm 2003).

\section{ECOLOGICAL ENHANCEMENT}

Once construction of an ORED is completed, the resultant physical structure could be a positive environmental enhancement because of an increase in the 3-D heterogeneity of the benthic habitat. An increase in habitat represents a greater colonization opportunity for benthos, opportunities for enhanced survival and growth, new trophic opportunities, recycling of local energy and increased refuge for juveniles of mobile species (Bohnsack \& Sutherland 1985). For the juvenile stages of many species shallow coastal areas are crucial for promoting individual growth, refuge and survival until such time as they are able to recruit to the adult population (Gregory \& Anderson 1997; Blaber et al. 2000). Habitats with greater physical heterogeneity have been shown to be functionally more important and increase fish abundance compared with more homogeneous areas of the same extent (Jenkins et al. 1997; Charbonnel et al. 2002).

Although no published data exist in the primary scientific literature, there are reports of existing ORED acting as artificial reefs that enhance the local ecosystem around the Baltic Sea coast (BorderWind 1998; Ecoserve 2000). Fishing records indicate an increase in yields post-construction that is assumed to be the result of extensive invertebrate colonization attracting fish (BorderWind 1998; Hoffman et al. 2000). The artificial reef effect therefore appears to offer evidence of a positive impact on the ecology of the area where the ORED is located. To be generally ecologically beneficial, however, ORED must do more than improve local biodiversity. There is a need to determine if enhancement is actually beneficial to the existing local populations of species by providing an additional, new source of recruits. Otherwise it may create wider problems by recruiting species to the site that would normally replenish the species populations of existing adjacent habitats on a regular basis. If the ORED acts as an ecological enhancement then daily management of operations, and particularly removal of habitat during decommissioning, will have to take this into account (Fig. 2). By extending this scenario to include multiple adjacent ORED then ecological changes will need to be determined not only on an ORED-by-ORED basis but also a cumulative basis, and include other existing habitats. Hence determination of local ecosystem connectivity, population (and possibly metapopulation) dynamics and food web interactions will require consideration of factors and processes at different spatial and temporal scales.

\section{Conservation and protected status}

Many coastal areas world-wide have some form of designation for the protection of species or habitats, while any ORED proposal will be required to consider the potential impact of the development on particular species and/or habitats. Often the species of concern 
are birds and mammals or rare or 'flagship' species (Simberloff 1998). Unfortunately, relatively low priority is given to most of the remaining coastal flora and fauna. While rare species, birds and mammals have intrinsic appeal, ecologically it is more important to consider impacts on the ecosystem structure and processes and key functional species (Simberloff 1998). This will require knowledge of which are the key species, how these species are affected as a result of an ORED, species resilience and how the ecosystem dynamics will respond both locally and in the wider context.

\section{Ecological-based mitigation}

True ecological mitigation has two main attributes: first it compels us to consider what would constitute an ecological stress; secondly, it provides us with an opportunity to determine how much of a stress we are prepared to allow. For industrial-scale ORED in coastal waters the most important ecological aspects to take into account concern ecosystem structure and function in terms of: habitat loss or gain, particularly the balance between species' requirements and habitat availability; effects on nutrient availability; changes in primary productivity and the consequent effect on production and biomass at different trophic levels; altered species diversity and composition; changes in size composition of the community; effects on species growth and mortality rate.

In order to minimize the impact on existing flora and fauna, ORED sites should have a sparse biological community, predominantly comprising opportunistic, resilient, colonizer species. Soft sediment communities are typically low in diversity and have species that are adapted to naturally unstable habitat conditions. However, locations that are used as a migratory or periodic habitat essential for life-history completion should be avoided. There may be a higher diversity of less resilient species at sites with more stable substrata and any ORED in such areas will affect a greater component of the ecosystem. Thus, from the outset, developments should take into consideration the ecological communities present and the ecologically relevant history of the area (e.g. previous degradation). In addition, an ORED should consider and if necessary mitigate against potential ecological problems throughout the construction, operation and decommission phases (Fig. 2).

\section{INTEGRATING ECOLOGY INTO ORED PLANS}

The stability of coastal ecosystems world-wide is under serious threat, hence ORED must be planned appropriately to protect the ecosystem from further degradation and to enhance it wherever possible. Ecologists must play a fundamental role in this process. Species may be adapted to a wide range of natural disturbances but disturbance related to ORED may still have positive or negative effects. As Hall (1994) points out in relation to fishing, although natural variation may be large this is no basis from an ecological stance to suggest that if human development is small it will have no effect.

As the number of ORED increases in the coastal zone, cumulative impact assessments are required to provide spatial and temporal assessment of the environmental impacts by taking account of the proximity of existing and planned future developments (Carryer \& Deeming 1998).

The biggest single problem for the integration of ecology into the planning and decision process for ORED remains the lack of appropriate knowledge. A stepped precautionary approach, such as the incremental one used in integrated fishery management (Symes 2000), may be most appropriate for ecologically based planning and management of ORED.

\section{Conclusions}

There is an urgent need to consider the ecological effects of the large increase in ORED in the coastal zone. Initiatives are required that facilitate ORED with due regard to ecological considerations and natural processes. This will require a wide-ranging perspective, adaptable monitoring and research based on our best understanding of coastal ecology, in order to sustain the ecosystem composition, structure and function whilst also assisting the wider goal of global carbon management. Ecology needs to be part of the process of ORED and at the same time offshore energy extractors need to be made aware of their role within the coastal ecosystem.

\section{Acknowledgements}

Abigail Casey, Jim Harris, Ian Gloyne-Phillips, Joe Spencer, Gordon Jones, Yi Huang, Gero Vella and Cranfield University colleagues discussed or contributed to many of the complex issues highlighted in this paper. Hong Yan, Art Myrberg and Steve Simpson provided material on underwater acoustics. The editorial team and two anonymous referees suggested improvements.

\section{References}

Atkinson, P.W., Clark, N.A., Bell, M.C., Dare, P.J., Clark, J.A \& Ireland, P.L. (2003) Changes in commercially fished shellfish stocks and shorebird populations in the Wash, England. Biological Conservation, 114, 127-141.

Barrett, R.T. \& Krasnov, Y.V. (1996) Recent responses to changes in stocks of prey species by seabirds breeding in the southern Barents Sea. ICES Journal of Marine Science, 53, $713-722$

Barrios, L. \& Rodriguez, A. (2004) Behavioural and environmental correlates of soaring-bird mortality at on-shore wind turbines. Journal of Applied Ecology, 41, 72-81.

Beale, C.M. \& Monaghan, P. (2004) Human disturbance: people as predation-free predators? Journal of Applied Ecology, 41, 335-343.

Blaber, S.J.M., Cyrus, D.P., Albaret, J.-J., Ching, C.V., Day, J.W., Elliott, M., Fonseca, M.S., Hoss, D.E., Orensanz, J., Potter, I.C. \& Silvert, W. (2000) Effects of fishing on the structure and functioning of estuarine and nearshore ecosystems. ICES Journal of Marine Science, 57, 590-602.
Ecology, 42,

605-615
2005 British Ecological Society, Journal of Applied 
613

Ecology and offshore renewable energy
Blaxter, J.H.S., Gray, J.A.B. \& Denton, E.J. (1981) Sound and startle responses in herring shoals. Journal of Marine Biological Association of UK, 61, 851-869.

Blyth, R.E., Kaiser, M.J., Edwards-Jones, G. \& Hart, P.J.B. (2004) Implications of a zoned fishery management system for marine benthic communities. Journal of Applied Eco$\log y, \mathbf{4 1}, 951-961$.

Bodznick, D. \& Boord, R.L. (1986) Electroreception in chondrichthyes: central anatomy and physiology. Electroreception (eds T.H. Bullock \& W. Heiligenberg), pp. 225 256. John Wiley \& Sons, New York, NY.

Bohnsack, J.A. \& Sutherland, D.L. (1985) Artificial reef research: a review with recommendations for future priorities. Bulletin of Marine Science, 37, 11-39.

BorderWind (1998) Offshore Wind Energy: Building a New Industry for Britain. Report for Greenpeace. BorderWind, Hexham, UK.

Bradbury, J.W. \& Veherencamp, S.L. (1998) Principles of Animal Communication. Sinauer. Associates Inc., Sunderlands, MA.

Bradshaw, C., Veale, L.O., Hill, A.S. \& Brand, A.R. (2000) The effects of scallop dredging on gravely seabed communities. The Effects of Fishing on Non-Target Species and Habitats: Biological, Conservation and Socio-Economic Issues (eds M.J. Kaiser \& S.J. de Groot), pp. 83-104. Blackwell Science, Oxford, UK.

Byrne, B.W. \& Houlsby, G.T. (2003) Foundations for offshore wind turbines. Philosophical Transactions of the Royal Society of London Series A, Mathematical Physical and Engineering Sciences, 361, 2909-2930.

Carpenter, S.R., Caraco, N.F., Correll, D.L., Howarth, R.W., Sharpley, A.N. \& Smith, V.H. (1998) Nonpoint pollution of surface waters with phosphorus and nitrogen. Ecological Applications, 8, 559-568.

Carryer, R. \& Deeming, K. (1998) Environmental risk for offshore windfarm developers: lessons from other industries. Proceedings of the Twentieth BWEA Wind Energy Conference Wind Energy: Switch on to Wind Power. Professional Engineering Publishing Ltd, Bury St Edmonds, UK.

Charbonnel, E., Serre, C., Ruitton, S., Harmelin, J.G. \& Jensen, A. (2002) Effects of increased habitat complexity on fish assemblages associated with large artificial reef units Science, 59, S208-S213.

Chow, J., Kopp, R.J. \& Portney, P.R. (2003) Energy resources and global development. Science, 302, 1528-1531.

CMACS (2003) A Baseline Assessment of Electromagnetic Fields Generated by Offshore Windfarm Cables. Report No. COWRIE EMF-01-2002, 66. Centre for Marine and Coastal Studies, Birkenhead, UK.

Coleman, F.C. \& Williams, S.L. (2002) Overexploiting marine ecosystem engineers: potential consequences for biodiversity. Trends in Ecology and Evolution, 17, 40-44.

Costanza, R., d'Arge, R., de Groot, R., Farber, S., Grasso, M., Hannon, B., Limburg, K., Naeem, S., O’Neill, R.V., Paruelo, J., Raskin, R.G., Sutton, P. \& van den Belt, M. (1997) The value of the world's ecosystem services and natural capital. Nature, 387, 253-260.

Dadswell, M.J. \& Rulifson, R. (1994) Macrotidal estuaries: a region of collision between migratory marine animals and tidal power development. Biological Journal of the Linnean Society, 51, 93-113.

Daskalov, G.M. (2002) Overfishing drives a trophic cascade in the Black Sea. Marine Ecology Progress Series, 225, $53-63$.

Dincer, I. (1999) Environmental impacts of energy. Energy Policy, 27, 845-854

2005 British Ecological Society, Journal of Applied Ecology, 42, 605-615

Dirksen, S., Spaans, A.L. \& van der Winden, J. (1996) Nachtelijke trek en vlieghoogtes van Steltlopers in het voorjaar over de noordelijke Havendam van Ijmuiden. Sula, 10, 129-142.

Drabsch, S.L., Tanner, J.E. \& Connell, S.D. (2001) Limited (French Mediterranean coast). ICES Journal of Marine

untrawled areas. ICES Journal of Marine Science, 58, 12611271

Dulvy, N.K., Sadovy, Y. \& Reynolds, J.D. (2003) Extinction vulnerability in marine populations. Fish and Fisheries, $\mathbf{4}$ $25-64$.

Dunnet, G.M., Furness, R.W., Tasker, M.L. \& Becker, P.H. (1990) Seabird ecology in the North Sea. Netherlands Journal of Sea Research, 26, 387-425.

Ecoserve (2000) Assessment of Impact of Offshore Wind Energy Structures on the Marine Environment. Volumes I and II. The Marine Institute, Dublin, Ireland.

Fernandez-Juricic, E. (2001) Avian spatial segregation at edges and interiors of urban parks in Madrid, Spain. Biodiversity and Conservation, 10, 1303-1316.

Fichet, D., Radenac, G. \& Miramand, P. (1998) Experimental studies of impacts of harbour sediment resuspension to marine invertebrate larvae: bioavailability of $\mathrm{Cd}, \mathrm{Cu}, \mathrm{Pb}$ and $\mathrm{Zn}$ and toxicity. Marine Pollution Bulletin, 36, 509518

Forman, R.T.T. \& Deblinger, R.D. (2000) The ecological road-effect zone of a Massachusetts (USA) suburban highway. Conservation Biology, 14, 36-46.

Fristedt, T., Moren, P. \& Soderberg, P. (2001) Acoustic and Electromagnetic Noise Induced by Wind Mills: Implications for Underwater Surveillance Systems Pilot Study. Report No. FOI-R-233-SE. Swedish Defence Research Agency, Stockholm, Sweden

Garthe, S. \& Huppop, O. (2004) Scaling possible adverse effects of marine wind farms on seabirds: developing and applying a vulnerability index. Journal of Applied Ecology, 41, 724-734.

Gill, A.B. (2003) The dynamics of prey choice in fish: the importance of prey size and satiation. Journal of Fish Bio$\log y, \mathbf{6 3 A}, 105-116$.

Gregory, R.S. \& Anderson, J.T. (1997) Substrate selection and use of protective cover by juvenile Atlantic cod Gadus morhua in inshore waters off Newfoundland. Marine Ecology Progress Series, 146, 9-20.

Hall, S.J. (1994) Physical disturbance and marine benthic communities: life in unconsolidated sediments. Oceanography and Marine Biology, An Annual Review, 32, 179-239.

Hall, S.J., Raffaelli, D. \& Thrush, S.F. (1994) Patchiness and disturbance in shallow water benthic assemblages. Aquatic Ecology: Scale, Pattern and Process (eds P.S. Giller, A.G. Hildrew \& D. Raffaelli), pp. 333-376. Blackwell Science, Cambridge, UK

Harvey, M., Gauthier, D. \& Munro, J. (1998) Temporal changes in the composition and abundance of the macrobenthic invertebrate communities at dredged material disposal sites in the Anse a Beaufils, baie des Chaleurs, eastern Canada. Marine Pollution Bulletin, 36, 41-55.

Harwood, J. \& Wilson, B. (2001) The implications of developments on the Atlantic Frontier for marine mammals. Continental Shelf Research, 21, 1073-1093.

Hoffman, E., Astrup, J., Larsen, F. \& Munch-Petersen, S. (2000) Effects of Marine Windfarms on the Distribution of Fish, Shellfish and Marine Mammals in the Horns Rev Area. Report to ELSAMPROJEKT A/S. Report No. Baggrundsrapport 24. Danish Institute for Fisheries Research, Lyngby, Denmark.

Holdway, D.A. (2002) The acute and chronic effects of wastes associated with offshore oil and gas production on temperate and tropical marine ecological processes. Marine Pollution Bulletin, 44, 185-203.

Houghton, J.E.T., Ding, Y., Griggs, D.J., Noguer, M., van der Linden, P.J., Dai, X., Maskell, K. \& Johnson, C.A. (2001) Climate Change 2001. The Scientific Basis. Cambridge University Press, Cambridge, UK. infaunal response to experimental trawling in previously
Jenkins, G.P., May, H.M.A., Wheatley, M.J. \& Holloway, M.G. (1997) Comparison of fish assemblages associated with seagrass and adjacent unvegetated habitats of Port Phillip Bay and Corner Inlet, Victoria, Australia, with 
emphasis on commercial species. Estuarine and Coastal Shelf Science, 44, 569-588.

Jennings, S., Kaiser, M.J. \& Reynolds, J.D. (2001) Marine Fisheries Ecology. Blackwell Science, Oxford, UK.

Kaiser, M.J. \& Jennings, S. (2002) Ecosystem effects of fishing. Handbook of Fish Biology and Fisheries, Vol. 2 (eds P.J.B. Hart \& J.D. Reynolds), pp. 342-366. Blackwell Science, Oxford, UK.

Kaiser, M.J. \& Spencer, B.E. (1996) The effects of beam-trawl disturbance on infaunal communities in different habitats. Journal of Animal Ecology, 65, 348-358.

Kalmijn, A.J. (1982) Electric and magnetic field detection in elasmobranch fishes. Science, 218, 916-918.

Kalmijn, A.J. (1988) Detection of weak electric fields. Sensory Biology of Aquatic Animals (eds J. Atema, R.R. Fay, A.N. Popper \& W.N. Tavolga), pp. 151-186. Springer, Berlin Heidelberg, New York.

Kinlan, B.P. \& Gaines, S.D. (2003) Propagule dispersal in marine and terrestrial environments: a community perspective. Ecology, 84, 2007-2020.

Leemans, R. \& Eickhout, B. (2004) Another reason for concern: regional and global impacts on ecosystems for different levels of climate change. Global Environmental Change, 14, 219-228.

Lugli, M., Yan, H.Y. \& Fine, M.L. (2003) Acoustic communication in two freshwater gobies: the relationship between ambient noise, hearing thresholds and sound spectrum. Journal of Comparative Physiology A, 189, 309-320.

McLusky, D.S., Bryant, D.M. \& Elliott, M. (1992) The impact of land-claim on macrobenthos, fish and shorebirds on the Forth estuary, eastern Scotland. Aquatic Conservation: Marine and Freshwater Ecosystems, 2, 211-222.

Mann, K.H. (2000) Ecology of Coastal Waters: with Implications for Management, 2nd edn. Blackwell Science, Malden, MA.

Mann, K.H. \& Lazier, J.R.N. (1996) Dynamics of Marine Ecosystems. Blackwell Science, London, UK.

Mason, C.F. (2002) Biology of Freshwater Pollution, 4th edn. Longman, London, UK.

Matthiessen, P. \& Law, R.J. (2002) Contaminants and their effects on estuarine and coastal organisms in the United Kingdom in the late twentieth century. Environmental Pollution, 120, 739-757.

May, R.M. (1994) The effects of spatial scale on ecological questions and answers. Large-Scale Ecology and Conservation Biology (eds P.J. Edwards, R.M. May \& N.R. Webb), pp. 1-18. Blackwell Scientific Publications, Oxford, UK.

Milinski, M. \& Parker, G.A. (1991) Competition for resources. Behavioural Ecology: An Evolutionary Approach (eds J.R. Krebs \& N.B. Davies), pp. 137-168. Blackwell Scientific Publications, Oxford, UK.

Montgomery, J., Carton, G., Voigt, R., Baker, C. \& Diebel, C. (2000) Sensory processing of water currents by fishes. Philosophical Transactions of the Royal Society of London B, 355, 1325-1327.

Myers, R.A. \& Worm, B. (2003) Rapid worldwide depletion of predatory fish communities. Nature, 423, 280-283.

Nedwell, J., Langworthy, J. \& Howell, D. (2004) Assessment of Sub-Sea Acoustic Noise and Vibration from Offshore Wind Turbines and its Impact on Marine Wildlife; Initial Measurements of Underwater Noise during Construction of Offshore Windfarms, and Comparison with Background Noise. Subacoustech Report 544R0424 to COWRIE. The Crown Estate, London, UK.

Newell, R.C., Seiderer, L.J., Simpson, N.M. \& Robinson, J.E. (2004) Impacts of marine aggregate dredging on benthic

(C) 2005 British Ecological Society, Journal of Applied Ecology, 42, 605-615 macrofauna off the south coast of the United Kingdom. Journal of Coastal Research, 20, 115-125.

Ormerod, S.J. (2003) Current issues with fish and fisheries: editor's overview and introduction. Journal of Applied Eco$\log y, \mathbf{4 0}, 204-213$.
Pauly, D., Christensen, V., Dalsgaard, J., Froese, R. \& Torresh, F.Jr. (1998) Fishing down marine food webs. Science, 279, 860-863.

Pauly, D., Christensen, V., Guenette, S., Pitcher, T.J., Sumaila, R., Walters, C.J., Watson, R. \& Zeller, D. (2002) Towards sustainability in world fisheries. Nature, 418, 689695.

Pearson, W.H., Skalski, J.R. \& Malme, C.I. (1992) Effects of sounds from a geophysical survey device on behavior of captive rockfish (Sebastes spp.). Canadian Journal of Fisheries and Aquatic Sciences, 49, 1434-1356.

Pelc, R. \& Fujita, R.M. (2002) Renewable energy from the ocean. Marine Policy, 26, 471-479.

Pimentel, D., Herz, M., Glickstein, M., Zimmerman, M., Allen, R., Becker, K., Evans, J., Hussain, B., Sarsfield, R., Grosfeld, A. \& Seidel, T. (2002) Renewable energy: current and potential issues. Bioscience, 52, 1111-1120.

Pimm, S.L. (1991) The Balance of Nature? Ecological Issues in the Conservation of Species and Communities. University of Chicago Press, Chicago, IL.

Popper, A.N. \& Fay, R.R. (1993) Sound detection and processing by fish: critical review and major research questions. Brain Behavior and Evolution, 41, 14-38.

Popper, A.N., Fewtrell, J., Smith, M.E. \& McCauley, R.D. (2003) Anthropogenic sound: effects on the behavior and physiology of fishes. Marine Technology Society Journal, 37, 35-40.

Pounds, J.A. \& Puschendorf, R. (2004) Clouded futures. Nature, 427, 107-109.

Rogers, C.E. \& McCarty, J.P. (2000) Climate change and ecosystems of the mid-atlantic region. Climate Research, 14, 235-244.

Ross, B.P., Lien, J. \& Furness, R.W. (2001) Use of underwater playback to reduce the impact of eiders on mussel farms. ICES Journal of Marine Science, 58, 517-524.

Schekkerman, H., Meininger, P.L. \& Meire, P.M. (1994) Changes in the waterbird populations of the Oosterschelde (SW Netherlands) as a result of large scale coastal engineering works. Hydrobiologia, 283, 509-524.

Scholik, A.M. \& Yan, H.Y. (2002) The effects of noise on the auditory sensitivity of the bluegill sunfish, Lepomos macrochirus. Comparative Biochemistry and Physiology Part A, 133, 43-52.

Simberloff, D. (1998) Flagships, umbrellas, and keystones: is single-species management passe in the landscape era? Biological Conservation, 83, 247-257.

Simpson, S.D., Meekan, M.G., McCauley, R.D. \& Jeffs, A. (2004) Attraction of settlement-stage coral reef fishes to reef noise. Marine Ecology Progress Series, 276, $263-$ 268.

Stillman, R.A., Goss-Custard, J.D., West, A.D., Durrell, S.E.A.L.D., McGrorty, S., Caldow, R.W.G., Norris, K.J., Johnstone, I.G., Ens, B.J., Van der Meer, J. \& Triplet, P. (2001) Predicting shorebird mortality and population size under different regimes of shellfishery management. Journal of Applied Ecology, 38, 857-868.

Symes, D. (2000) Integrated management: the implications of an ecosystem approach to fisheries management. The Effects of Fishing on Non-Target Species and Habitats: Biological, Conservation and Socio-Economic Issues (eds M.J. Kaiser \& S.J. de Groot), pp. 366-382. Blackwell Scientific Publishing, Oxford, UK.

Tasker, M.L., Camphuysen, C.J., Cooper, J., Garthe, S., Montevecchi, W.A. \& Blaber, S.J.M. (2000) The impacts of fishing on marine birds. ICES Journal of Marine Science, 57, 531-547.

Thomas, C.D., Cameron, A., Green, R.E., Bakkenes, M., Beaumont, L.J., Collingham, Y.C., Erasmus, B.F.N., de Siqueira, M.F., Grainger, A., Hannah, L., Hughes, L., Huntley, B., van Jaarsveld, A.S., Midgley, G.F., Miles, L., Ortega-Huerta, M.A., Peterson, A.T., Phillips, O.L. \& 
615

Ecology and

offshore renewable

energy
Williams, S.E. (2004) Extinction risk from climate change. Nature, 427, 145-148.

Tricas, T.C. \& New, J.G. (1998) Sensitivity and response dynamics of elasmobranch electrosensory primary afferent neurons to near threshold fields. Journal of Comparative Physiology A, 182, 89-101.

Tyack, P.L. \& Clark, C.W. (2000) Communication and acoustic behaviour of dolphins and whales. Springer Handbook of Auditory Research: Hearing by Whales and Dolphins (eds W.W.L. Au, A.N. Popper \& R.R. Fay), pp. 156-224. Springer, New York, NY.

Tyler, C.R., Jobling, S. \& Sumpter, J.P. (1998) Endocrine disruption in wildlife: a critical review of the evidence. Critical Reviews in Toxicology, 28, 319-361.

Van Dalfsen, J.A., Essink, K., Madsen, H.T., Birklund, J., Romero, J. \& Manzanera, M. (2000) Differential response of macrozoobenthos to marine sand extraction in the
North Sea and Western Mediterranean. ICES Journal of Marine Science, 57, 1439-1445.

Walker, T.I. (2001) Review of Impacts of High Voltage Direct Current Sea Cables and Electrodes on Chondrichthyan Fauna and Other Marine Life. Basslink Supporting Study No. 29. Marine and Freshwater Resources Institute No. 20. Marine and Freshwater Resources Institute, Queenscliff, Australia.

Westerberg, H. (1999) Effect of HVDC cables on eel orientation. Technische Eingriffe in Marine Lebensraume. Bundesamt fur International Naturschutzakademie, pp. 1-6. Insel Vlim, Sweden.

Wiltschko, R. \& Wiltschko, W. (1995) Magnetic Orientation in Animals. Springer-Verlag, Berlin, Germany.

Received 22 June 2004; final copy received 15 April 2005 Editor: Steve Rushton
(C) 2005 British

Ecological Society, Journal of Applied Ecology, 42,

605-615 